\title{
BRAIN DEATH AND COMPUTED TOMOGRAPHY ANGIOGRAPHY: EFFECT OF SKULL DEFECT
}

\author{
Tuğçe MENGí1 ${ }^{1}$, Hüseyin Alper KIZILOĞLU², Hadiye Ş̧iRÍN ${ }^{3}$ \\ ${ }^{1}$ Niğde Training and Research Hospital, Neurology Clinic, Niğde, TURKEY \\ ${ }^{2}$ Niğde Training and Research Hospital, Radiology Clinic, Niğde, TURKEY \\ ${ }^{3}$ Ege University Faculty of Medicine, Department of Neurology, İzmir, TURKEY
}

\begin{abstract}
INTRODUCTION: The skull defects such as fractures and operations (craniectomy or craniotomy) in patients with suspected brain death may decrease intracranial pressure and lead to erroneous results in diagnosis with ancillary tests such as computed tomography angiography (CTA). In this study, our aim is to analyze the results of CTA in patients with and without skull defects diagnosed clinically with brain death.

METHODS: Patients with clinical signs of brain death who underwent CTA as an ancillary test were evaluated retrospectively. The patients were categorized into two groups: the group with skull defects (skull defect +) and the group without skull defects (skull defect -).

RESULTS: Sixteen patients with a clinical diagnosis of brain death who underwent CTA were evaluated. It was found that $75 \%(12 / 16)$ of the patients had skull defects. Four of the 12 patients with skull defects had fractures. Six of the patients with skull defects had craniectomy and 2 had craniotomy. Contrast filling was detected in 6 patients (37.5\%) at the first CTA according to Frampas criteria. All patients with contrast filling in the first CTA had skull defects. After clinical signs of brain death, radiological brain death was diagnosed significantly later in the group with skull defects [median time 2 (0.57) days] than in the group without skull defects [median time $0.5(0.5-0.5)$ days], $(p=0.013)$.

DISCUSSION AND CONCLUSION: Although the number of patients is limited, our study has shown the difficulties in CTA in patients with skull defects. According to our findings, the false negative rate of CTA in brain death diagnosis has increased in patients with skull defects. Brain death has been diagnosed later in patients with skull defects. These findings bring up the controversies about the use of different evaluation criteria for CTA or the use of ancillary tests other than CTA in patients with skull defects.
\end{abstract}

Keywords: Brain death, computed tomography angiography, craniectomy, skull defect.

\footnotetext{
Address for Correspondence: Tuğçe Mengi, MD. Niğde Training and Research Hospital, Tertiary Intensive Care Unit, Niğde, Turkey. Phone: +903882322220 E-mail: tugceangin@gmail.com Received: $19.04 .2021 \quad$ Accepted: 02.05.2021

ORCID IDs: Tuğçe Mengi 0000-0003-3298-5767, Hüseyin Alper Kızlloğlu 0000-0003-2370-7319, Hadiye Şirin 0000-0001-6256-9487.

Please cite this article as following: Mengi T, Kızıloğlu HA, Şirin H. Brain death and computed tomography angiography: Effect of skull defect. Turkish Journal of Cerebrovascular Diseases 2021; 27(2): 153-159. doi: 10.5505/tbdhd.2021.74507
} 


\section{BEYIN ÖLÜMÜ VE BILGISAYARLI TOMOGRAFI ANJIOGRAFI: KAFATASI DEFEKTININ ETKISİ}

\section{ÖZ}

GİRIȘ ve AMAÇ: Beyin ölümü șüphesi olan hastalarda kırık ve operasyonlar (kraniyektomi veya kraniyotomi) gibi kafatası defektileri kafa içi basıncını düşürebilir ve bilgisayarlı tomografi anjiografi (BTA) gibi destekleyici testler ile tanı konmada hatalı sonuçlara yol açabilir. Bu çalışmada, amacımız klinik olarak beyin ölümü teşhisi konulmuş kafatası defekti olan ve olmayan hastalarda BTA sonuçlarını analiz etmektir.

YÖNTEM ve GEREÇLER: Beyin ölümü klinik bulgularına sahip ve destekleyici test olarak BTA uygulanan hastalar retrospektif olarak değerlendirildi. Hastalar iki gruba ayrıldı: kafatası defekti olan grup (kafatası defekti +) ve kafatası defekti olmayan grup (kafatası defekti -).

BULGULAR: Klinik olarak beyin ölümü tanısı olan ve BTA uygulanan 16 hasta değerlendirildi. Hastaların \% 75'inde $(12 / 16)$ kafatası defekti olduğu tespit edildi. Kafatası defekti olan 12 hastanın 4'ünde kırık mevcuttu. Diğer kafatası defekti olan hastaların 6'sında kraniyektomi, 2'sinde kraniyotomi mevcuttu. Frampas kriterlerine göre ilk BTA'da 6 hastada (\% $37,5)$ kontrast dolumu saptandı. İlk BTA'da kontrast dolumu saptanan hastaların tamamında kafatası defekti mevcuttu. Klinik beyin ölümü bulguları sonrası kafatası defekti olan grupta [medyan süre 2 (0,5-7) gün], kafatası defekti olmayan gruba [medyan süre 0,5 (0,5-0,5) gün] göre radyolojik beyin ölümü tanısı anlamlı olarak daha geç konuldu $(p=0,013)$.

TARTIŞMA ve SONUÇ: Hasta sayısı kısıtlı olsa da çalışmamız kafatası defekti olan hastalarda BTA uygulaması hakkındaki zorlukları göstermiştir. Bulgularımıza göre kafatası defekti olan hastalarda BTA'nın beyin ölümü tanısı koymada yanlış negatiflik oranı artmaktadır. Kafatası defekti olan hastalara beyin ölümü tanısı daha geç konmaktadır. Bu bulgular, kafatası defekti olan hastalarda BTA için farklı değerlendirme kriterlerinin kullanılması veya BTA dışındaki diğer destekleyici testlerin kullanılması konusundaki tartışmaları gündeme getirmektedir.

Anahtar Sözcükler: Beyin ölümü, bilgisayarlı tomografi anjiografi, kraniyektomi, kafatası defekti.

\section{INTRODUCTION}

Brain death is the loss of all activities of the parts of central nervous system that reside within the skull, that is, brain, brain stem and cerebellum, permanently in other words, irreversibly. The main clinical signs of brain death include coma, loss of brainstem reflexes, and apnea (1). According to international standards, clinical diagnosis of brain death is made based on clinical criteria. However, under certain clinical conditions, ancillary tests may also be necessary. These tests vary depending on different types of legislation in countries (2).

The skull defects such as fractures and operations (craniectomy or craniotomy) in patients with suspected brain death may decrease intracranial pressure and lead to erroneous results in diagnosis with ancillary tests such as computed tomography angiography (CTA) (3). This study aimed to analyze CTA results in patients with and without skull defects who were clinically diagnosed with brain death.

\section{MATERIAL AND METHODS}

Study design: Patients who were followed up in adult intensive care units (ICUs) between August 2019 and August 2020, had clinical signs of brain death and underwent CTA as an ancillary test were evaluated.

Turkish Journal of Cerebrovascular Diseases 2021; 27(2): 153-159
The study was conducted in accordance with the Research and Publication Ethics and the principles of the Declaration of Helsinki. The study's ethics committee approval was obtained from the Niğde Ömer Halisdemir University Ethics Committee (Number: 45269, Date: 09/04/2021).

The records of patients who were clinically diagnosed with brain death in our database and their information in the hospital automation system were evaluated retrospectively. Patients' age, gender, cause of coma, presence of skull defect (fracture, craniectomy, craniotomy), CTA, time, CTA findings, presence of follow-up CTA, time from clinical to a radiological diagnosis of brain death, and APACHE II score were recorded in the data collection form.

Patients were divided into two groups: the group with skull defects (skull defect + ) and the group without skull defects (skull defect -).

Brain death diagnosis protocol of our hospital: In our hospital, the diagnosis of brain death is made based on the Turkish Neurological Society Diagnostic Guidelines for Brain Death (1). Prerequisites are evaluated in comatose patients with severe brain injury. The second stage is started for patients who meet clinical criteria for brain death. These patients are assessed for coma and brainstem areflexia and scheduled for an apnea test. 
Within the framework of this protocol, ancillary tests are definitely performed for each patient, and CTA is performed depending on the decision made in line with the facilities of our hospital. Following consultations, neurological examination, apnea test, and CTA, patients are evaluated for the final decision of brain death. Brain death declaration is made after the decision of brain death by two physicians consisting of a neurologist or neurosurgeon and anesthesiology and reanimation or intensive care specialist.

Technical data: Patients with a clinical diagnosis of brain death are radiologically evaluated using Siemens Somatom go.Up CT device. Multiphase CTA examination starts with non-contrast imaging. The second phase is the arterial phase. In the arterial phase, the distance from the aortic arch to the skull vertex is included in the field of view. Thus, the aortic arch and the main vascular structures originating from the aortic arch are evaluated. Then, venous phase and late venous phase images are acquired at intervals of about 810 seconds without using an extra contrast agent. In the venous and late venous phases, the distance from the foramen magnum to the vertex is included in the image field to visualize only vascular structures of the brain. As the scan protocol, pre-contrast, 30-second (arterial phase), 70 -second, and 420-second images with a slice thickness of $0.8 \mathrm{~mm}$, including brain parenchyma and head and neck, are acquired.

Image analysis: In evaluating images, the presence of contrast media filling in external carotid artery branches and the absence of contrast material filling in intracranial arterial and venous vessels on arterial phase examination and later phases according to Frampas criteria is used for the radiological diagnosis of brain death. Cortical branches of bilateral middle cerebral arteries and internal cerebral veins are evaluated according to Frampas criteria (4).

Statistical analysis: The data obtained from the study were recorded in the standard software called "Statistical Package for Social Sciences for Windows 22.0". In data analysis, categorical variables were expressed as frequencies and percentages. Continuous variables were given as median value (minimum-maximum). Continuous variables were evaluated with the Mann-Whitney $\mathrm{U}$ test and categorical data with Fisher's exact test. A p-value $<0.05$ was considered statistically significant.

\section{RESULTS}

Sixteen patients with a clinical diagnosis of brain death who had undergone CTA were evaluated. The median age was 46 (range, 20-76) years, and $50 \%$ were female. The causes of coma were traumatic brain injury $(n=9,56.25 \%)$, intracerebral hemorrhage $(n=4,25 \%)$, ischemic stroke $(n=1$, $6.25 \%)$, subarachnoid hemorrhage $(n=1,6,25 \%)$ and hypoxic-ischemic encephalopathy after cardiorespiratory arrest $(n=1,6.25 \%)$. Skull defect was identified in $75 \%(12 / 16)$ of the patients. Four of 12 patients with skull defects had fractures. Of the patients with skull defects, 6 underwent craniectomy, and 2 had a craniotomy. It was found that external ventricular drainage was performed on one patient who underwent craniectomy during the ICU followup. The demographic, clinical, imaging and outcome characteristics of the group with skull defect (skull defect + ) and the group without skull defect (skull defect -) are summarized in Table 1.

After clinical brain death diagnosis, CTA was performed for all patients as an ancillary test. The median time from a clinical diagnosis of brain death to first CTA was 0.5 (0.5-7) days. CTA was performed on 9 patients on the same day of diagnosis because their neurological examination was consistent with brain death, while it was later performed on 6 patients. All patients who underwent CTA late had skull defects. In 6 patients with skull defects and delayed CTA, CTA was performed after a median of 3 days following clinical brain death findings. A diagnosis of radiological brain death was made according to the Frampas criteria, and contrast filling on initial CTA was not identified in 10 patients $(62.5 \%)$. Four of the patients without contrast filling had no skull defect. Six patients had skull defects, and CTA was performed late on 5 of these patients.

Contrast filling of intracranial arterial and venous vessels was noted on initial CTA in six patients (37.5\%). The clinical features and CTA interpretations of patients with contrast filling on initial CTA are summarized in Table 2. All patients with contrast filling had skull defects. Using Frampas criteria, the sensitivity of the initial CTA was $100 \%$ $(4 / 4)$ in patients without skull defect, $50 \%(2 / 4)$ in those with fractures, $100 \%(2 / 2)$ in those with craniotomy, and $33.3 \%(2 / 6)$ with craniectomy.

Five of the patients with contrast filling underwent follow-up CTA. No contrast filling was detected in two patients according to Frampas criteria on the follow-up CTA, and brain death was diagnosed in 1 patient because contrast filling was not detected on the third follow-up CTA. Brain death was declared for 13 patients. Brain death 
was not declared due to the detection of contrast filling according to Frampas criteria on CTA examination of 3 patients with clinical signs of brain death, including apnea test positivity. All 3 patients for whom brain death was not declared had a history of craniectomy.

CTA slices of some patients with and without skull defects are shown in the figure.

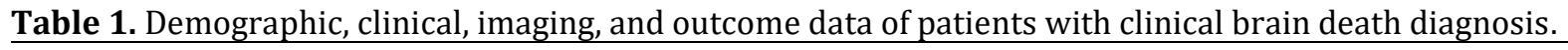

\begin{tabular}{|c|c|c|c|}
\hline & $\begin{array}{c}\text { Skull defect + } \\
(n=12)\end{array}$ & $\begin{array}{c}\text { Skull defect - } \\
(n=4)\end{array}$ & $\mathbf{P}$ \\
\hline \multicolumn{4}{|l|}{ Demographic features } \\
\hline Age, median years (min-max) & $41 \%(20-76)$ & $54(24-59)$ & 0.855 \\
\hline Female gender, $\%(\mathrm{n})$ & $41.7 \%(5)$ & $75 \%(3)$ & 0.569 \\
\hline \multicolumn{4}{|l|}{ Cause of coma } \\
\hline Traumatic brain injury, \% (n) & $66.7 \%(8)$ & $25 \%(1)$ & 0.262 \\
\hline Intracerebral hemorrhage, $\%(\mathrm{n})$ & $16.7 \%(2)$ & $50 \%(2)$ & 0.245 \\
\hline Ischemic stroke, \% (n) & $8.3 \%(1)$ & $0 \%$ & - \\
\hline Hypoxic-ischemic encephalopathy & $0 \%$ & $\% 25(1)$ & - \\
\hline Subarachnoid hemorrhage, $\%$ (n) & $8.3 \%(1)$ & $0 \%$ & - \\
\hline APACHE II, median (min-max) & $29.5 \%(21-37)$ & $26 \%(20-36)$ & 0.761 \\
\hline Presence of blood flow on initial CTA*, \% (n) & $50 \%(6)$ & $0 \%$ & 0.234 \\
\hline Time from clinical brain death to first CTA, median days (min-max) & $3 \%(0.5-7)$ & $0.5 \%(0.5-0.5)$ & 0.106 \\
\hline Time from clinical to radiological brain death diagnosis, median days (min-max) & $2 \%(0.5-7)$ & $0.5 \%(0.5-0.5)$ & 0.013 \\
\hline Brain death declaration, $\%(\mathrm{n})$ & $75 \%(9)$ & $100 \%(4)$ & 0.529 \\
\hline
\end{tabular}

Table 2. Clinical, radiological, and outcome characteristics of patients with contrast material filling on initially computed tomography angiography.

\begin{tabular}{|c|c|c|c|c|c|c|}
\hline Patient No & 1 & 2 & 3 & 4 & 5 & 6 \\
\hline Skull defect & Fracture & Craniectomy & $\begin{array}{l}\text { Craniectomy, } \\
\text { EVD }^{*}\end{array}$ & Craniectomy & Craniectomy & Fracture \\
\hline Cause of coma & $\mathrm{TBI}^{+}$ & TBI & $\mathrm{ICH}^{\ddagger}$ & $\mathrm{ICH}$ & İskemik inme & TBI \\
\hline $\begin{array}{l}\text { 1. Enhancement on CTA according to } \\
\text { Frampas criteria }\end{array}$ & Yes & Yes & Yes & Yes & Yes & Yes \\
\hline 1. Venous enhancement on CTA & Yes & Yes & Yes & Yes & Yes & Yes \\
\hline $\begin{array}{l}\text { 2. Enhancement on CTA according to } \\
\text { Frampas criteria }\end{array}$ & No & - & Yes & No & Yes & Yes \\
\hline 2. Venous enhancement on CTA & No & - & No & No & No & No \\
\hline $\begin{array}{l}\text { 3. Enhancement on CTA according to } \\
\text { Frampas criteria }\end{array}$ & - & - & - & - & - & No \\
\hline 3. Venous enhancement on CTA & - & - & - & - & - & No \\
\hline Brain death declaration & Yes & No & No & Yes & No & Yes \\
\hline
\end{tabular}

\section{DISCUSSION AND CONCLUSION}

In our study, the sensitivity of CTA was found to be lower in patients with clinical brain death findings and skull defect, especially craniectomy, compared to those without skull defect, but this difference was not statistically significant. In the skull defect group, the diagnosis of radiological brain death was made later after clinical brain death findings $(p<0.05)$. Although the number of patients is limited, our study has demonstrated the difficulties regarding CTA use on patients with skull defects. Computed tomography angiography offers important advantages, such as rapid, reproducible, relatively inexpensive, and minimally invasive techniques $(5,6)$.

However, there is no consensus on diagnostic criteria, and there are multiple image interpretation models in use $(6,7)$.

Computed tomography angiography was first reported by Dupas et al. in 1998 (8) as an ancillary test with $100 \%$ specificity for diagnosing 

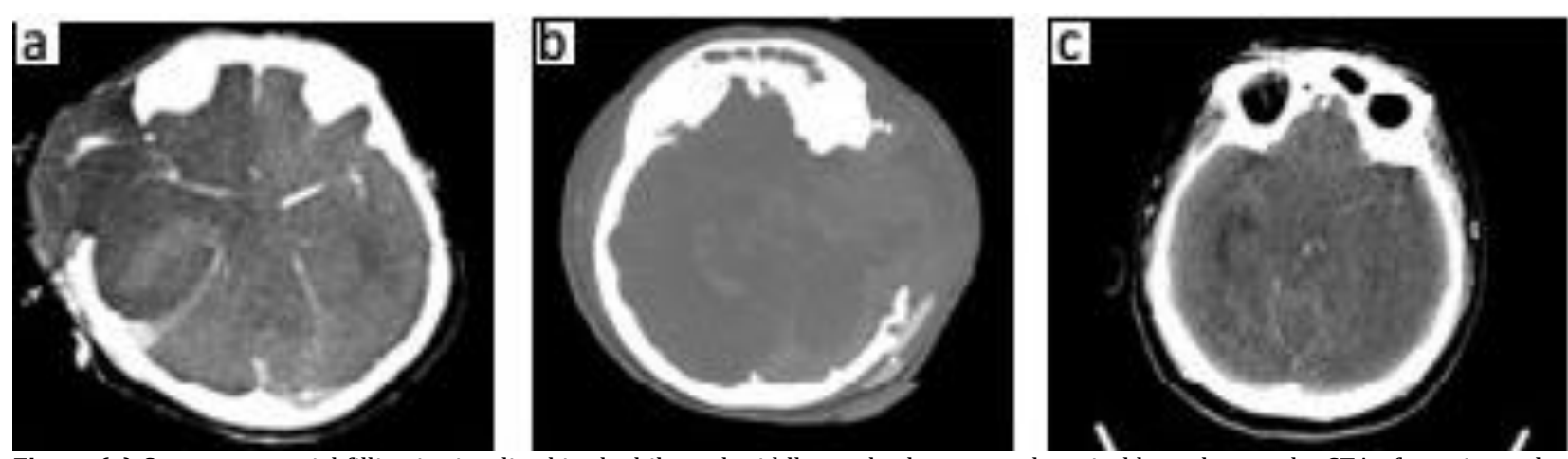

Figure (a) Contrast material filling is visualized in the bilateral middle cerebral artery and cortical branches on the CTA of a patient who underwent decompressive craniectomy. (b) The MIP images of a patient who underwent decompressive craniectomy and declared brain dead show contrast material filling in the external carotid artery end branches in the scalp but no contrast material filling in the intracranial branches. (c) The initial CTA of a patient without a skull defect shows no intracranial contrast material filling. While contrast material filling is visualized in the external carotid artery end branches in the scalp, it is not observed in the intracranial branches.

brain death. It was reported that 14 patients with clinical brain death had no enhancement in the cortical segments of the middle cerebral arteries (2), bilateral pericallosal arteries (2), bilateral internal cerebral veins (2), and the great cerebral vein (1). Unenhanced 7 vessels are defined as a 7 point scale on CTA (8). The major disadvantage of this scale is the stasis filling. The cause is the progression of the intravascular iodinated contrast agent in the high-resistance distal vascular bed without the ability to perfuse the brain parenchyma (3). Stasis filling is observed at a higher rate on CTA than on cerebral angiography, leading to false negativity $(3,9)$. In 2009 , Frampas et al. (4) defined a short 4-point scale (cortical branches of bilateral middle cerebral arteries and internal cerebral veins), concluding that it is effective and reliable for the diagnosis of brain death with $85.7 \%$ sensitivity in the absence of contrast enhancement in middle cerebral arteries and internal cerebral veins on CTA (Frampas criteria). Many studies have shown that the Frampas criteria are more sensitive to diagnosing brain death than the 7-point scale (10). In the following years, discussions on the timing of the arterial and venous phase, the number of vessels evaluated, the sensitivity of CTA, and stasis filling have increased $(3,7,9,10)$.

According to the Monro-Kellie hypothesis, intracranial pressure results from the balance between the cerebrospinal fluid, blood, and brain parenchyma within the rigid compartment of the skull. The increased intracranial pressure causes a displacement of the cerebrospinal fluid towards the spinal subarachnoid space, followed by pressure equalization through intracranial vascular collapse. This collapse occurs first in the venous compartment and then in the arterial compartment (3). Therefore, in patients with suspected brain death, a skull defect caused by fracture, operations such as craniectomy and craniotomy may reduce intracranial pressure. As a result of changes in intracranial hemodynamics, the diagnostic accuracy of ancillary tests that evaluate cerebral blood circulation may decrease (3). However, there is limited literature on this subject $(3,11,12)$. Berenguer et al. (12) compared nuclear medicine perfusion test and CTA in 25 clinical brain death patients. That study reported that three patients with skull defects had minimal enhancement on CTA and no brain perfusion in nuclear medicine perfusion test (12). Nunes et al. (3) found skull defects in 26 of 48 brain death patients. When CTA of 26 patients with skull defects was interpreted according to Frampas criteria, CTA of 6 of them was not found to be consistent with brain death. When Frampas criteria were used in this study, the sensitivity of CTA was found to be $95.5 \%$ in patients without skull defect, $87.5 \%$ in patients with craniotomy, and $60 \%$ in patients with craniectomy (3). These rates question the validity of Frampas criteria in cases of skull defect such as craniectomy. When Frampas criteria were used in our study, the sensitivity of the initial CTA was $63 \%$. While the sensitivity was $100 \%$ in patients without skull defects, it was found to be $50 \%$ in patients with fractures, $100 \%$ in patients with craniotomy, and $33.3 \%$ in patients with craniectomy. The duration of diagnosis of radiological brain death was 
longer in the group with skull defect $(p<0.05)$. Brain death was not declared due to the detection of contrast filling according to Frampas criteria on CTA of 3 patients with clinical signs of brain death, including apnea test positivity. All 3 patients, who were not declared brain dead, had a history of craniectomy. These rates and figures reveal the difficulties in the radiological diagnosis of brain death in cases with skull defects, especially craniectomy. Literature data are underlining the importance of venous evaluation with CTA in patients with craniectomy. The study by Marchand et al. (13) compared the 4-point scale (Frampas criteria) with a venous evaluation with CTA and reported that venous evaluation was more effective in patients with decompressive craniectomy. In our study, intracranial contrast filling was detected on the initial CTA of 6 patients, both according to Frampas criteria and in the venous phase of CTA. Five patients underwent follow-up CTA. The venous evaluation of 2 patients showed no intracranial venous contrast material filling on follow-up CTA. Still, brain death was not declared for these 2 patients due to the detection of contrast agent filling in the cortical branches of the middle cerebral artery.

It has been shown that the rate of false negativity of CTA increases as the skull defect enlarges (3). External ventricular drainage was performed on one of our patients after decompressive craniectomy. Contrast filling in the intracranial arteries was noted on the CTA of this patient. It was decided to follow up with transcranial Doppler ultrasonography. CTA was repeated because the transcranial Doppler ultrasonography findings suggested radiological brain death. While contrast material filling was not detected in the venous evaluation on the second CTA, brain death was not declared due to the detection of contrast material filling in the cortical branches of the middle cerebral artery. The patient died of cardiac arrest during the intensive care follow-ups. A similar case series was presented by Frisardi et al. (11). In that article, contrast enhancement was detected in intracranial arteries on CTA in 2 patients with craniectomy and clinical signs of brain death. Transcranial Doppler ultrasonography showed no blood flow in the same arteries. Since contrast material filling was detected on the CTA of both patients, the diagnosis of brain death could not be made, and the patients died of cardiac arrest (11).
The major limitation of our study is not performing invasive cerebral angiography on patients with contrast material filling on CTA. The second limitation is our small sample size. This is probably why the rate of detection of contrast filling on CTA of patients with skull defects was not statistically significant. The third limitation of the study is its retrospective design.

No ancillary test can document all loss of neuronal function for the definition of brain death. Therefore, the need for ancillary tests is addressed by some authors. Although there is consensus on the clinical criteria for brain death in Europe, there are significant differences in the use and interpretation criteria of ancillary tests accepted by law. As a result of the evaluation of the studies, the French Society of Neuroradiology recommended that the left and right internal cerebral veins and the great cerebral vein be evaluated if arterial enhancement is noted on CTA in cases of decompressive craniectomy (11). There is no recommendation regarding patients with skull defects in the guidelines published by associations and legal regulations in our country.Furthermore, most of the studies conducted in Turkey did not draw attention to patients with skull defects and did not mention the limitations of ancillary tests. However, several questions are waiting to be answered for cases of skull defects with clinical signs of brain death. Should ancillary tests be performed for these patients? Which ancillary test should be preferred? When should the test be repeated if CTA shows contrast material filling? Which criteria should be preferred for the interpretation of CTA? Should a declaration of brain death be made in the case of detection of contrast agent filling on CTA and findings consistent with brain death in another test evaluating cerebral blood flow? We hope that these questions will be answered by good quality, large-scale, prospective studies on brain death. For such large-scale studies, centers performing CTA should cooperate. Making adjustments in the legal legislation will fill the gaps in diagnosing brain death and ancillary tests.

In conclusion, this study reveals the difficulties of CTA in patients with skull defects. Ancillary tests should perhaps be performed later for patients with a skull defect who are hemodynamically stable. Furthermore, the use of other interpretation models instead of a 4-point scale may increase sensitivity and reduce false- 
negative rates in patients with skull defects undergoing CTA.

\section{REFERENCES}

1. Arsava EM, Demirkaya Ş, Dora B, et al. Turkish Neurological Society- Diagnostic guidelines for brain death. Turk J Neurol 2014 ;20: 101-104.

2. Escudero D, Valentín MO, Escalante JL, et al. Intensive care practices in brain death diagnosis and organ donation. Anaesthesia 2015; 70(10): 1130-1139.

3. Nunes DM, Maia ACM Jr, Boni RC, et al. Impact of Skull Defects on the Role of CTA for Brain Death Confirmation. AJNR Am J Neuroradiol 2019; 40(7): 1177-1183.

4. Frampas E, Videcoq M, de Kerviler E, et al. CT angiography for brain death diagnosis. AJNR Am J Neuroradiol 2009; 30(8): 1566-1570.

5. Drake M, Bernard A, Hessel E. Brain Death. Surg Clin North Am 2017; 97(6): 1255-1273.

6. Greer DM, Shemie SD, Lewis A, et al. Determination of Brain Death/Death by Neurologic Criteria: The World Brain Death Project. JAMA 2020; 324(11): 1078-1097.

7. Taylor T, Dineen RA, Gardiner DC, et al. Computed tomography (CT) angiography for confirmation of the clinical diagnosis of brain death. Cochrane Database Syst Rev 2014; 2014(3): CD009694.

8. Dupas B, Gayet-Delacroix M, Villers D, et al. Diagnosis of brain death using two-phase spiral CT. AJNR Am J Neuroradiol 1998; 19(4): 641-647.

9. Rizvi T, Batchala P, Mukherjee S. Brain Death: Diagnosis and Imaging Techniques. Semin Ultrasound CT MR 2018; 39(5): 515-529.

10. Gastala J, Fattal D, Kirby PA, et al. Brain death: Radiologic signs of a non-radiologic diagnosis. Clin Neurol Neurosurg 2019; 185: 105465.
11. Frisardi F, Stefanini M, Natoli S, et al. Decompressive craniectomy may cause diagnostic challenges to assess brain death by computed tomography angiography. Minerva Anestesiol 2014; 80(1): 113-118.

12. Berenguer CM, Davis FE, Howington JU. Brain death confirmation: comparison of computed tomographic angiography with nuclear medicine perfusion scan. J Trauma 2010; 68(3): 553-559.

13. Marchand AJ, Seguin P, Malledant Y, et al. Revised CT angiography venous score with consideration of infratentorial circulation value for diagnosing brain death. Ann Intensive Care 2016; 6(1): 88.

Ethics

Ethics Committee Approval: The study was approved by Ömer Halisdemir University Ethical Committee (Number: 45269, Date: 09.04.2021).

Informed Consent: The authors declared that it was not considered necessary to get consent from the patients because the study was a retrospective study.

Copyright Transfer Form: Copyright Transfer Form was signed by all authors.

Peer-review: Internally peer-reviewed.

Authorship Contributions: Surgical and Medical Practices: TM, HAK. Concept: TM, HȘ. Design TM, HŞ. Data Collection or Processing: TM, HAK. Analysis or Interpretation: TM, HAK, HŞ. Literature Search: TM. Writing: TM, HȘ.

Conflict of Interest: No conflict of interest was declared by the authors.

Financial Disclosure: The authors declared that this study received no financial support. 